\title{
Vaccine programmes facing threat of 'donor fatigue'
} sponsible for preventing an estimated three million deaths a year from childhood diseases are in danger of losing funds provided by international donor agencies because of their success, according to scientists attending an international meeting at the London School of Hygiene and Tropical Medicine (LSHTM) last week.

Since 1974, the proportion of the world's children receiving a full course of the six major childhood vaccines has increased from less than 20 per cent to 80 per cent. But there is now concern that the very success of these immunization programmes may encourage donors to channel funds into other areas of public health-care instead.

The programmes receive money from the World Health Organization (WHO), the United Nations Children's Fund(UNICEF), the United Nations Development Programme (UNDP) and the World Bank.

According to Ralph Henderson, assistant director-general of WHO, sustaining the momentum of immunization programmes is crucial. "Five or 10 years ago, there was complacency about vaccines for preventable infectious diseases," he said at the meeting. "But immunization programmes have changed global epidemiology."

Henderson expressed particular concern that infectious organisms might at any time develop new strains resistant to current vaccines, to which the population would be highly susceptible. "We are sitting on a time bomb", he said, referring to the current levels of immunity to diphtheria in the adult population in Africa.

The campaign to eradicate polio from the Western Hemisphere, launched by the Pan American Health Organization in May 1985, was an attempt to revive donor interest by
London. Global vaccination programmes re-

creating new goals. But, although the campaign looks highly promising in that no cases of polio have been reported from the Americas for the past two years, the programme is turning out to be more expensive than initially thought. Henderson estimates that between $\$ 1$ and $\$ 2$ billion will be needed annually until the year 2000 to sustain it.

According to Felicity Cutts, the director of the conference and a senior lecturer at

\section{IMAGE UNAVAILABLE FOR COPYRIGHT REASONS}

\section{Immunization is under threat.}

LSHTM, the eradication of polio is feasible as long as the infrastructure for delivering the vaccine is in place. But in the lowest-income countries, which are mostly in sub-Saharan Africa, eradication cannot succeed, she claims, unless that infrastructure is first strengthened with the help of resources from the richer, developed countries.

The national coverage level of BCG (the current vaccine against tuberculosis) for children less than one year old in Cameroon, West Africa, fell from 95 per cent in 1990 , following a universal children's immunization campaign, to 52 per cent in 1992. Peter Ndumbe, director of the Centre for Study and Control of Communicable Diseases at the University of Yaoundé, Cameroon, attributes this to "a new and infectious disease called 'donor fatigue"'. Laura Spinney

\section{Saltpetre dump blamed for Russian explosion}

Moscow. A leading Russian expert on the physics of explosions has suggested that a mysterious series of major blasts three years ago in the small town of Savoso, $150 \mathrm{~km}$ from Moscow, was caused by the ignition of more than $\mathbf{3 0}$ tonnes of ammonium nitrate (Norway saltpetre).

The explosion, on 12 April 1991, left a large crater and generated wide-ranging rumours. Hypotheses on its origin in leading Russian papers included an earthquake, a meteorite impact or even radiation from an unidentified flying object.

There has been no official explanation. But a study carried out by Konstantin Shvedov, a laboratory director at the
Russian Academy of Sciences' Chemical Physics Institute in Moscow, concludes that it was caused by 32 tonnes of ammonium nitrate that had been stored there.

According to Shvedov, characteristics such as the crater size and shape, and the distribution of chemical products of the explosion, were similar to those of a wellstudied incident in Oppau, Germany, in 1921. In addition, the impact on the environment corresponds to the total amount of ammoniac saltpetre known to be stored at the site.

Shvedov speculates that the explosion could have been triggered by a heavy object falling from a plane - or even by arson.

\section{India seeks details of 'miracle' mix of microorganisms}

New Delhi. Live microorganisms imported and released into the environment in violation of safety guidelines have created a furore among scientists in India. At the centre of the controversy is a private agency at Atami in Japan, known as the International Nature Farming Research Centre (INFAC).

Several acres of crop fields have been sprayed with a microbial culture "gifted" by INFRC to farmers with the promise that it will increase "crop yield, cut fertilizer bills, purify sewage, recycle kitchen garbage and even eliminate foul smell in cattle sheds".

According to the Japanese body, the culture contains "at least" 80 microorganisms beneficial to the soil. But it is keeping their identity and composition secret. INFRC plans to sell the preparation at $\$ 2$ a litre.

Many Indian scientists have been shocked by the ease with which the Japanese have inoculated Indian soil with strains of bacteria about which Indians know nothing. "We lap up anything made in Japan," says Balamani Bezbarua, a microbiologist at the Regional Research Laboratory in Assam. "But I didn't think we would go blindly for their bugs without knowing what they are."

Bezbarua makes up her own culture of microbes isolated from local soil, but is careful to treat crops only with the enzymes secreted by the bugs, and not the bugs themselves. "Release of exotic microbes in living form without knowing their identity is inviting disaster in the long run," she says.

The Department of Biotechnology (DBT), the custodian of safety standards in research in life sciences, claims that it was unaware that the Japanese preparation contained living microbes. Under DBT guidelines, release of imported organisms in living form needs approval from an expert committee that examines requests for such releases from Indian and foreign agencies. According to DBT, INFRC made no formal application.

INFRC staff provided the culture to their Indian "contacts" for distribution to farmers. A spokesman for INFRC said that when bottles were sent by post, the customs refused to clear them without authority.

INFRC also gave samples for field trials to individual scientists. One such trial at the Indian Agricultural Research Institute in New Delhi was stopped by its director, S. K. Sinha, who said it was going on without his knowledge.

INFRC claims that its product is made up of mixed cultures of naturally occurring species of organisms and is totally harmless. But Sinha says that there is still no justification for introducing the microbes to India without going through the proper channels.

K. S. Jayaraman 